\title{
DETERMINANT HARGA SAHAM PERUSAHAAN SEKTOR PERTAMBANGAN DI BURSA EFEK INDONESIA
}

\author{
Achmad Nizar Hidayat ${ }^{1}$, Yuyun Isbanah ${ }^{2}$ \\ Universitas Negeri Surabaya ${ }^{1,2}$ \\ Email korespondensi: yuyunisbanah@unesa.ac.id
}

\begin{abstract}
The purpose of this research is to analyze the influence of debt ratio, size, earnings per share, dividend policy, and money supply to stock price in mining Sector Company listed in Indonesia stock exchange period 2011-2015. This research uses the type of causality research and the data used is secondary data. Sampling technique by purposive sampling and obtained by eight companies as research object. The analysis method used is multiple linear regression analysis. The results show the debt ratio, size, earnings per share, dividend payout ratio, and dividend yield effect on stock prices of mining companies. While the money supply does not affect to stock price of mining companies. The recommendation of this research is that company need to consider debt ratio, size, earnings per share, dividend payout ratio and dividend yield in making company policy, because can affect stock price movement of company and become an alternative investment decision-making for investors.
\end{abstract}

Keyword: stock price, debt ratio, size, earnings per share, dividend policy, and money supply

Received: 15 Pebruari 2018 Reviewed: 21 Pebruari 2018

Accepted: 16 April 2018

Published: 19 April 2018

\section{PENDAHULUAN}

Harga saham merupakan suatu parameter keinginan dari penanam modal untuk memiliki saham suatu perusahaan. Jika harga saham suatu perusahaan mengalami kenaikan terus-menerus, maka para penanam modal menilai bahwa perusahaan tersebut berhasil dalam mengendalikan usahanya. Kepercayaan para penanam modal sangat berguna bagi emiten, karena semakin banyak orang yang percaya terhadap emiten maka keinginan untuk menanamkan modal pada emiten semakin kuat. Semakin banyak permintaan terhadap saham suatu emiten maka dapat menaikkan harga saham tersebut. Sebaliknya, jika harga saham mengalami penurunan terus-menerus berarti dapat mengurangi nilai emiten dimata para pemegang saham (Nuel,2015). 
Menurut Kodrat dan Indonanjaya (2010), analisis tentang harga saham yang biasa digunakan terdiri atas dua jenis yaitu analisis teknikal yang dipopulerkan oleh Charles H. Dow dengan The Dow Theory dan analisis fundamental yaitu analisa ekonomi, analisa industri, dan analisa perusahaan. Saham menjadi suatu alternatif menanamkan modal di pasar modal yang banyak dinginkan oleh para pemegang saham karena keuntungannya bisa lebih besar dan dana yang diperlukan untuk menanam modal juga tidak besar jika dibandingkan dengan obligasi.

Tujuan Perusahaan dalam melakukan pemodalan saham adalah untuk memaksimumkan kesejahteraan bagi pemegang saham dengan cara mengoptimalkan nilai saham perusahaan sehingga berdampak pada harga saham tersebut (Fahmi, 2015:3). Penanaman modal dalam bentuk saham terdapat resiko yang tinggi sesuai dengan prinsip investasi yaitu high risk high return, low risk low return. Seorang pemegang saham haruslah memahami tentang harga saham dan sering melakukan analisis terlebih dahulu dalam mengambil keputusan investasi saham karena dalam pergerakan harga saham tidak dapat diprediksi secara benar.

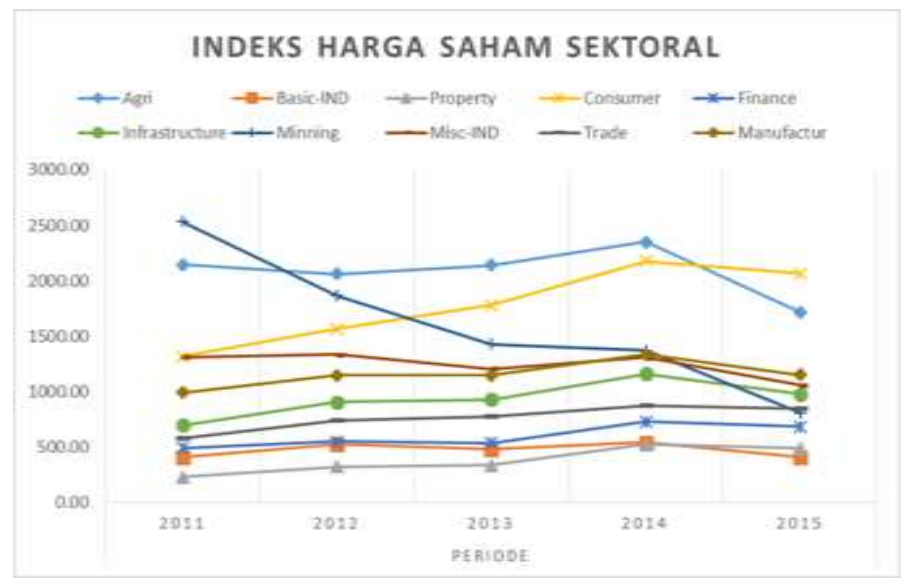

Sumber: BEI (Diolah Penulis, 2017)

Gambar 1. Data Perkembangan Indeks Harga Saham Sektoral tahun 2011-2015

Gambar 1 menunjukkan pergerakan harga saham pada berbagai sektor selama 2011-2015 yang terlihat pada sektor pertambangan menunjukkan sektor yang menunjukkan signifikansi penurunannya dari tahun ke tahun dari pada berbagai sektor lainnya. Menurut Soda (2016) Pada tahun 2015 menjadi tahun yang buruk bagi sektor pertambangan karena terdapat rekor baru yang dibukukan oleh 40 perusahaan pertambangan terbesar di dunia. Dari rangkaian laporan industri PwC seperti yang diterima oleh Majalah Tambang, 40 perusahaan pertambangan global terbesar mencatat kerugian bersih kolektif (US\$27 miliar). Hal tersebut merupakan yang pertama dalam sejarah di mana kapitalisasi pasar turun sebesar 37\%, sehingga berdampak pada kapitalisasi pasar di Indonesia. 
Keseluruhan perusahaan pertambangan yang tercatat di Bursa Efek Indonesia turun dari Rp 255 triliun pada 31 Desember 2014 menjadi Rp 161 triliun pada tanggal 31 Desember 2015. Penurunan sebesar 37\% ini terutama dipicu oleh jatuhnya harga komoditas. Hal tersebut di atas, menjadi fenomena yang menarik untuk diteliti dan dianalisis lebih lanjut. Dalam menganalisa faktor perusahaan terdapat 2 faktor, yaitu faktor internal dan eksternal perusahaan. Faktor internal mencerminkan kinerja perusahaan yang berpengaruh dalam hal apakah perusahaan tersebut berkembang atau sebaliknya. Ukuran kinerja dapat dilihat dari laporan keuangan perusahaan dan dapat dilakukan analisis untuk mencari suatu rasio keuangan (Azizah, 2016). Jenis rasio keuangan yang sering digunakan dalam menilai kinerja perusahaan adalah rasio likuiditas, rasio aktivitas, rasio solvabilitas, rasio profitabilitas dan rasio pasar (Murhadi, 2015:56). Sedangkan faktor eksternal pada penelitian ini adalah jumlah uang beredar yang dapat berpengaruh pada pergerakan harga saham.

Selain dua faktor tersebut kebijakan dividen juga sangat penting karena dapat mempengaruhi kesempatan investasi perusahaan, harga saham, dan arus pendanaan. Dengan kebijakan dividen dapat menyediakan informasi mengenai performa perusahaan. oleh karena itu, masing-masing perusahaan menetapkan kebijakan dividen yang berbeda-beda, karena kebijakan dividen tersebut berpengaruh terhadap suatu nilai perusahaan dalam membayar dividen kepada pemegang sahamnya (Brigham dan Houston, 2011:217).

Menurut Sartono (2010:120), rasio hutang menunjukkan proporsi atas penggunaan utang untuk membiayai investasinya. Perusahaan yang tidak mempunyai hutang berarti menggunakan modal sendiri 100\%. Penggunaan utang itu sendiri bagi perusahaan mengandung 3 dimensi, yaitu: (1) pemberi kredit akan menitikberatkan pada besarnya jaminan atas kredit yang diberikan; (2) dengan menggunakan utang perusahaan dapat keuntungan yang lebih besar dari beban tetapnya sehingga keuntungan pemilik perusahaan dapat meningkat; dan (3) dengan menggunakan utang maka pemilik memperoleh dana serta tidak kehilangan pengendalian perusahaan. Dalam hubungannya dengan harga saham hutang perusahaan sangat berpengaruh. Karena jika perusahaan itu banyak berhutang maka otomatis penghasilan perusahaan itu pun kecil atau sedikit maka harga sahamnya pun akan rendah. Dalam penelitian Warrad (2016) dan Buigut dkk. (2013) menemukan bahwa rasio hutang terdapat pengaruh terhadap harga saham. Aveh dan Vitor (2017), Hussainey dkk. (2011) dan Viandita dkk. (2013), menunjukkan hasil pada variabel rasio hutang terdapat pengaruh negatif terhadap harga saham. Sedangkan penelitian Barakat (2014) menunjukkan hasil berbeda pada variabel rasio hutang tidak terdapat pengaruh terhadap harga saham. Menurut Riyanto (2008:313), ukuran perusahaan (size) menggambarkan besar kecilnya suatu perusahaan yang ditunjukkan oleh total nilai ekuitas, nilai penjualan atau nilai aset suatu perusahaan. Jadi, ukuran perusahaan merupakan ukuran besarnya aset atau nilai kapitalisasi yang dimiliki oleh perusahaan. Dalam 
hubungannya dengan harga saham ukuran perusahaan dapat menjadi tolak ukur harga saham perusahaan besar dengan perusahaan kecil. Dalam Penelitian Aveh dan Vitor (2017), Khan (2014) dan Gunarso (2014), terdapat pengaruh positif terhadap harga saham. Sedangkan Ghauri (2014) dan Hussainey dkk. (2011) menunjukkan hasil pada variabel size yang memiliki pengaruh hubungan negatif terhadap harga saham.

Laba per lembar saham (Earning Per Share) merupakan suatu parameter tingkat nilai perusahaan dan juga salah satu cara guna mengukur keberhasilan dalam mencapai keuntungan bagi para pemilik saham dalam perusahaan. Menurut Fahmi (2015:93) laba per lembar saham adalah bentuk imbalan keuntungan yang diberikan kepada para pemegang saham dari setiap lembar saham yang dimilikinya. Sehingga EPS sangat berpengaruh dalam suatu pergerakan harga saham yang ditunjukkan pertimbangan antara besarnya keuntungan bersih yang diperoleh investor atau pemegang saham terhadap jumlah lembar saham. Dalam Penelitian Sukhija (2014), Hunjra dkk (2014) serta Aveh dan Vitor (2017) yang menunjukkan hasil pada variabel Earning per Share (EPS) terdapat pengaruh positif terhadap harga saham. Sedangkan Khan (2012) menunjukkan hasil pada variabel EPS tidak terdapat pengaruh terhadap harga saham.

Menurut Sartono, (2010: 281) Kebijakan dividen adalah keputusan apakah laba yang diperoleh perusahaan akan dibagikan kepada pemegang saham sebagai dividen atau ditahan dalam bentuk laba ditahan untuk pembiayaan investasi di masa yang akan datang. Kebijakan dividen memiliki arti yang sangat berguna, karena secara tidak langsung kebijakan dividen mempunyai informasi yang berguna untuk para pemegang saham. Para pemegang saham yang menginginkan yield (dividen) atau capital gain kedua-duanya sama-sama menginginkan dan membutuhkan informasi mengenai kebijakan dividen pada perusahaan. Informasi mengenai kebijakan dividen ini dapat juga menjadi suatu aspek yang berguna apakah investor akan menanamkan modalnya atau tidak. Investasi yang dilakukan oleh investor pasti akan berdampak pada harga saham yang dimiliki oleh perusahaan tersebut. Dalam penelitian Hunjra dkk (2014) dan Sharif dkk (2015) menunjukkan hasil pada variabel DPR terdapat hubungan yang positif terhadap harga saham. Sedangkan Hussainey dkk. (2011) serta Anastassia dan Firnanti (2014) menunjukkan bahwa variabel DPR menunjukkan hasil yang negatif terhadap harga saham. Hasil tersebut berbeda dengan Sukhija (2014) yang menunjukkan hasil pada variabel DPR tidak terdapat pengaruh terhadap harga saham. Hussainey (2011) serta Anastassia dan Firnanti (2014) yang menunjukkan pada variabel dividend yield terdapat pengaruh yang positif terhadap harga saham. Sedangkan Hunjra dkk. (2014), Barakat (2014), Masum (2014) serta Aveh dan Viktor (2017) menunjukkan hasil dari variabel dividend yield terdapat pengaruh terhadap harga saham tetapi negatif, bahkan Ghauri (2014) menemukan hasilnya adalah dividend yield tidak berpengaruh terhadap harga saham. 
Jumlah uang beredar merupakan aspek ekonomi yang dapat mempengaruhi harga saham. Apabila jumlah uang beredar tinggi maka harga saham akan naik. Hal tersebut dikarenakan ketika jumlah uang beredar meningkat maka orang akan cenderung melakukan investasi. Ketika para penanam modal menyimpan uang mereka dalam bentuk suatu investasi saham maka harga saham perusahaanpun akan mengalami peningkatan yang berdampak pada meningkatnya harga saham (Samsul, 2006:210). Harga saham di bursa efek tidak selalu tetap, adakalanya meningkat ataupun menurun, tergantung pada permintaan dan penawaran, dimana terjadi fluktuasi harga saham tersebut menjadikan bursa efek menarik bagi penanam modal. Penelitian khan (2014) yang menunjukkan hasil bahwa money supply atau jumlah uang beredar berpengaruh negatif terhadap harga saham. Bosupeng (2014) dan Akbar dkk. (2012) menemukan bahwa variabel jumlah uang beredar berhubungan positif terhadap harga saham. Sedangkan Al-Tamimi dkk. (2011) serta Kusuma dan badjra (2016) menunjukkan hasil yang berbeda yaitu jumlah uang beredar tidak berpengaruh terhadap harga saham.

Berdasarkan uraian latar belakang di atas tujuan penelitian ini untuk menganalisis pengaruh rasio hutang, ukuran perusahaan, earning per share, kebijakan dividen dan jumlah uang beredar secara parsial terhadap harga saham pada perusahaan sektor pertambangan yang tercatat di Bursa Efek Indonesia (BEI) periode 2011-2015.

\section{KAJIAN PUSTAKA DAN PENGEMBANGAN HIPOTESIS Teori Sinyal (Signalling Theory)}

Teori sinyal adalah teori yang menganalisis tentang naik turunnya harga saham di pasar, sehingga akan berdampak terhadap pengaruh keputusan investor (Fahmi, 2015:96). Keputusan investor dalam menangkap sinyal tersebut didapat dari petunjuk apapun yang terjadi dari kondisi saham suatu perusahaan. Tanggapan para investor terhadap sinyal sangat mempengaruhi lingkungan bursa, mereka akan bereaksi dengan berbagai cara dalam menelaah sinyal tersebut, seperti memburu saham yang dijual atau melakukan aktivitas dalam bentuk diam dan menunggu (wait and see) perkembangan yang ada baru kemudian mengambil langkah selanjutnya. Teori sinyal dalam penelitian ini digunakan untuk menjelaskan pengaruh rasio hutang, ukuran perusahaan, earning per share, dividend payout ratio, dividend yield dan jumlah uang beredar terhadap harga saham.

\section{Harga Saham}

Menurut Sartono (2010:34) Pengertian harga saham adalah nilai dimana orang bersedia membayar untuk setiap lembar sahamnya. Sedangkan menurut Brigham dan Houston (2011:11), harga saham atau harga pasar saham merupakan nilai saham berdasarkan petunjuk yang diperkirakan, tetapi memiliki kemungkinan salah seperti yang dilihat oleh investor marginal. 


\section{Rasio Hutang}

Menurut Brigham dan Houston (2011:143) Rasio hutang merupakan skala seluruh hutang terhadap seluruh aset, yang digunakan untuk menaksirkan dana yang diberikan oleh kreditur. Seluruh hutang termasuk seluruh kewajiban lancar dan hutang jangka panjang.

\section{Ukuran Perusahaan}

Ghauri (2014) menyatakan bahwa ukuran perusahaan berarti seberapa besarnya ekuitas dari suatu perusahaan. variabel ini dapat dihitung dengan mengalikan nominal saham dengan jumlah saham yang diterbitkan. Menurut Khan (2014), Ukuran perusahaan berarti rasio kapitalisasi pasar.

\section{Earning Per Share (EPS)}

Earning per share (laba per lembar) saham adalah bentuk imbalan keuntungan yang diberikan kepada para pemegang saham dari setiap lembar saham yang dimilikinya (Fahmi, 2015:93).

\section{Dividend Payout Ratio (DPR)}

Dividend payout ratio (DPR) merupakan iktikat manajemen untuk membagi kinerjanya kepada pemegang saham. DPR banyak manfaatkan dalam penilaian sebagai cara pengestimasian dividen untuk periode yang akan datang (Hadi 2013:81).

\section{Dividend Yield (DY)}

Dividend Yield adalah parameter untuk mengukur kinerja saham berdasarkan dividen yang dibagikan. Semakin tinggi tingkat dividend yield maka bisa menarik minat para investor untuk menginvestasikan dananya pada perusahaan tersebut (Hadi 2013:81).

\section{Jumlah Uang Beredar}

Menurut Herlambang dkk. (2001: 115), uang dikenal M1, M2, M3, dan seterusnya. Istilah tersebut menunjukkan tingkat likuiditas dari uang dan derivatifnya. M1 merupakan uang yang likuid (biaya mempergunakannya sangat rendah). Termasuk dalam golongan ini adalah uang kartal (uang yang dicetak pemerintah) serta tabungan yang dapat diambil setiap saat. M2 meliputi M1 ditambah derivatif uang yang kurang likuid dibandingkan M1, seperti deposito jangka pendek dan sebagainya (deposito ini sering disebut sebagai quasi money). M3 melingkupi M2 ditambah derivatif uang yang kurang likuid dibanding M2 dan seterusnya. 


\section{Pengaruh Rasio Hutang terhadap Harga Saham}

Rasio hutang menunjukkan proporsi atas penggunaan utang untuk membiayai investasinya. Semakin tinggi rasio tersebut maka semakin besar risiko yang dihadapi, dan investor akan meminta tingkat keuntungan yang semakin tinggi (Sartono, 2010:121). Menurut Brigham dan Huoston (2011:143) pemegang saham mungkin menginginkan lebih banyak hutang karena akan memperbesar laba yang diharapkan sehingga dapat berpengaruh terhadap harga saham suatu perusahaan. Hasil tersebut sesuai dengan penelitian Warrad (2016) bahwa rasio hutang berpengaruh terhadap harga saham. Sedangkan menurut Barakat (2014) menunjukkan hasil yang berbeda bahwa tidak memiliki hubungan terhadap harga saham.

H1 : Rasio hutang berpengaruh terhadap harga saham pada perusahaan sektor pertambangan.

\section{Pengaruh Ukuran Perusahaan terhadap Harga Saham}

Ukuran perusahaan (size) menggambarkan besar kecilnya suatu perusahaan yang ditunjukkan oleh total nilai equity, nilai penjualan atau nilai aset suatu perusahaan (Riyanto, 2008:313). Semakin besar suatu perusahaan maka akan lebih mudah memperoleh modal di pasar modal dibanding dengan perusahaan kecil, karena kemudahan akses tersebut berarti perusahaan yang besar memiliki fleksibilitas yang lebih besar pula (Sartono, 2010:249). Jadi, ukuran perusahaan merupakan ukuran atau seberapa besarnya aset yang dimiliki oleh perusahaan. Dalam hubungannya dengan harga saham ukuran perusahaan dapat menjadi tolak ukur harga saham perusahaan besar dengan perusahaan kecil. Penelitian dari khan (2014) bahwa variabel ukuran perusahaan berpengaruh positif terhadap harga saham, sedangkan Ghauri (2014) menyatakan bahwa ukuran perusahaan berpengaruh negatif terhadap harga saham.

H2 : Ukuran perusahaan berpengaruh terhadap harga saham pada perusahaan sektor pertambangan.

\section{Pengaruh Earning per Share terhadap Harga Saham}

Earning Per Share merupakan salah satu indikator tingkat nilai perusahaan dan juga salah satu cara guna mengukur keberhasilan dalam mencapai keuntungan bagi para pemilik saham dalam perusahaan. Menurut Fahmi (2015:93) laba per lembar saham adalah bentuk pemberian keuntungan yang diberikan kepada para pemegang saham dari setiap lembar saham yang dimilikinya. Semakin tinggi EPS, semakin tinggi juga keuntungan yang diberikan kepada pemegang saham dari setiap lembar saham yang dimilikinya, sehingga akan berbengaruh terhadap minat para investor untuk membeli saham. Penelitian dari Sukhija (2014) yang menunjukkan hasil pada variabel Earning per Share (EPS) terdapat hubungan positif terhadap harga saham. Sedangkan Khan (2012) menunjukkan hasil pada variabel EPS terdapat hubungan Signifikan negatif terhadap harga saham. 
H3 : Earning per share berpengaruh terhadap harga saham pada perusahaan sektor pertambangan.

\section{Pengaruh Kebijakan Dividen terhadap Harga Saham}

Dividend Payout Ratio (DPR) merupakan rasio hasil perbandingan antara dividen dengan laba yang tersedia bagi para pemegang saham biasa. DPR banyak digunakan dalam penilaian sebagai cara pengestimasian dividen untuk periode yang akan datang. Semakin besar DPR maka akan mengurangi kemampuan perusahaan untuk investasi sehingga akan menurunkan tingkat pertumbuhan perusahaan selanjutnya akan menurunkan harga saham (Sartono, 2010:281). Penelitian dari Sukhija (2014) yang menunjukkan hasil pada variabel DPR tidak terdapat hubungan terhadap harga saham. Sedangkan Penelitian dari Sharif dkk (2015) menunjukkan hasil pada variabel DPR terdapat hubungan yang positif terhadap harga saham.

H4 : Dividend payout ratio berpengaruh terhadap harga saham pada perusahaan sektor pertambangan.

Dividend Yield menyediakan suatu ukuran komponen pengembalian total yang dihasilkan dividen, dengan menambahkan apresiasi harga yang ada. Beberapa investor menggunakan dividend yield sebagai suatu ukuran risiko dan sebagai suatu penyaring investasi, yaitu mereka akan berusaha menginvestasikan dananya dalam saham yang menghasilkan dividend yield yang tinggi. Sehingga semakin besar dividen yield yang diterima maka dapat menarik minat paara investor untuk menginvestasikan dananya pada perusahaan tersebut (Hadi, 2013:79). Penelitian dari Ghauri (2014) yang menunjukkan variabel dividend yield tidak terdapat pengaruh terhadap harga saham. Sedangkan Penelitian dari Masum (2014) meneliti tentang Kebijakan dividen dan Dampaknya Terhadap Harga Saham menunjukkan hasil dari variabel dividend yield terdapat pengaruh terhadap harga saham tetapi negatif.

H5 : Dividend yield berpengaruh terhadap harga saham pada perusahaan sektor pertambangan.

\section{Pengaruh Jumlah Uang Beredar terhadap Harga Saham}

Jumlah uang beredar merupakan Faktor ekonomi makro yang dapat mempengaruhi harga saham. Apabila jumlah uang beredar tinggi harga saham akan diturunkan yang bertujuan supaya investor akan membeli saham yang diterbitkan. Harga saham di bursa efek tidak selamanya tetap, adakalanya meningkat ataupun menurun, tergantung pada permintaan dan penawaran, dimana terjadi fluktuasi harga saham tersebut menjadikan bursa efek menarik bagi investor. Hal tersebut sesuai Penelitian dari Akbar dkk (2012) tentang hubungan harga saham dengan ekonomi makro menunjukkan hasil variabel jumlah uang beredar berhubungan positif terhadap harga saham. Dan Penelitian dari khan 
(2014) yang meneliti pengaruh respon faktor makroekonomi terhadap harga saham yang menunjukkan variabel jumlah uang beredar (money supply) berpengaruh negatif terhadap harga saham.

H6 : Jumlah uang beredar berpengaruh terhadap harga saham pada perusahaan sektor pertambangan.

\section{METODE PENELITIAN}

Jika ditinjau dari tujuan penelitiannya menurut Malhotra (2010:113), merupakan jenis penelitian kausalitas yang bertujuan untuk mendapatkan bukti atas hubungan sebab akibat antara variabel bebas terhadap variabel terikat. Sumber data penelitian ini menggunakan data sekunder, karena data dalam penelitian ini diperoleh secara tidak langsung dari sumbernya yaitu data yang sudah dipublikasikan di Bursa Efek Indonesia dan Badan Pusat Statistik Indonesia.

Populasi pada penelitian ini adalah perusahaan sektor pertambangan yang tercatat di Bursa Efek Indonesia periode 2011-2015 sebanyak 41 perusahaan. Teknik pengambilan sampel yang digunakan dalam penelitian ini adalah purposive sampling yang menghasilkan sebanyak delapan perusahaan sebagai sampel penelitian.

Teknik pengumpulan data pada penelitian ini menggunakan teknik dokumentasi yang digunakan untuk mencari data-data yang diperlukan seperti, data pada laporan keuangan.

Tabel 1. Definisi Operasional Variabel

\begin{tabular}{|c|c|}
\hline Variabel & Rumus \\
\hline Harga Saham (Stock Price) & SP $=$ Closing Price di BEI pada akhir tahun \\
\hline Rasio Hutang (Debt Ratio) & Rasio Hutang $=\frac{\text { Total Hutang }}{\text { Total Aset }}$ \\
\hline Ukuran Perusahaan & Size $=\log n$ (jumlah saham beredar $x$ harga pasar per lembar) \\
\hline Earning per Share & $\mathrm{EPS}=\frac{\text { laba setelah pajak }(\mathrm{EAT})}{\text { Jumlah saham yang beredar(JSB) }}$ \\
\hline Dividend Payout Ratio & $\mathrm{DPR}=\frac{\text { Dividend per share }(\mathrm{DPS})}{\text { Earning per share }(\mathrm{EPS})}$ \\
\hline Dividend Yield & $\mathrm{DY}=\frac{\text { Dividend Per Share }(\mathrm{DPS})}{\text { Harga Pasar Saham }}$ \\
\hline Jumlah Uang Beredar & $\mathrm{MS}=\mathrm{Log}$ Total M2 \\
\hline
\end{tabular}

Sumber: Data diolah penulis

Teknik analisis data menggunakan Uji Asumsi Klasik yang terdiri dari uji normalitas (uji Kolmogrov-Smirnov), multikolonieritas dengan melihat nilai tolerance dan nilai dari variance inflation factor, heteroskedastisitas (uji park), dan autokorelasi (uji Run Test). Selanjutnya dilakukan uji regresi dengan model formula 1 sebagai berikut

$$
S P=\alpha+\beta_{1} \mathrm{DR}+\beta_{2} \text { Size }+\beta_{3} \mathrm{EPS}+\beta_{4} \mathrm{DPR}+\beta_{5} \mathrm{DY}+\beta_{6} \mathrm{MS}+\mathrm{e} \ldots . .(1)
$$


Keterangan:

SP = Harga Saham (Stock Price)

$\alpha \quad=$ Konstanta

$\beta_{1} . \beta_{6}=$ Koefisien regresi masing-masing variabel

$D R \quad=$ Rasio Hutang (debt ratio)

Size = Ukuran Perusahaan $($ size $)$

EPS = Earning Per Share (EPS)

DPR $=$ Dividend Payout Ratio (DPR)

DY = Dividend Yield $(\mathrm{DY})$

MS = Jumlah Uang Beredar (Money Suppy)

$\mathrm{e} \quad=$ Standard error

\section{HASIL DAN PEMBAHASAN}

Hasil uji asumsi klasik diketahui bahwa pengujian normalitas dengan Kolmogrov-Smirnov diketahui nilai assymp sig. (2-tailed) adalah 0,108 > 0,05. Hal tersebut menunjukkan bahwa data penelitian berdistribusi normal. Dari hasil pengujian multikolinieritas, nilai tolerance $\geq 0,01$ dan nilai VIF $\leq 10$ pada seluruh variabel penelitian. Sehingga dapat disimpulkan tidak terjadi gejala multikolinieritas pada model regresi.

Dari hasil pengujian autokorelasi menggunakan Run Test diketahui bahwa asymp. Sig (2-tailed) adalah 0,108. Hal tersebut dapat dismpulkan bahwa data penelitian tidak terjadi gejala autokorelasi.

Berdasarkan pengujian heteroskedastisitas menggunakan uji park terdapat variabel yang nilsi sig $\leq 0,05$. Sehingga data terdapat gejala heteroskedastisitas. Menurut Ghozali (2016:167) transformasi data dilakukan agar dapat memenuhi asumsi klasik pada heteroskedastisitas, pada penelitian ini data dilakukan transformasi dalam bentuk Logaritma Natural dengan menggunakan rumus LN(x). Setelah dilakukan transformasi, data tidak terjadi gejala heteroskedastisitas lagi dengan nilai $\operatorname{sig} \geq 0,05$.

Tabel 2. Pengujian Hipotesis

\begin{tabular}{lcccc}
\hline \multirow{2}{*}{ Model } & \multicolumn{2}{c}{$\begin{array}{c}\text { Unstandardized } \\
\text { Coefficients }\end{array}$} & t & Sig. \\
\cline { 2 - 3 } & $\mathrm{B}$ & Std. Error & & \\
\hline \hline (Constan) & -1.952 & 6.918 & -0.282 & 0.78 \\
\hline Ln_DR & -0.43 & 0.173 & -2.481 & 0.018 \\
\hline Ln_Size & 2.844 & 1.226 & 2.319 & 0.027 \\
\hline Ln_EPS & 0.756 & 0.048 & 15.87 & 0.000 \\
\hline Ln_DPR & 0.713 & 0.115 & 6.209 & 0.000 \\
\hline Ln_DY & -0.423 & 0.072 & -5.842 & 0.000 \\
\hline Ln_MS & -0.292 & 0.318 & -0.916 & 0.366
\end{tabular}

Sumber: output SPSS, 2017 
Berdasarkan hasil uji F diketahui bahwa tingkat signifikansi sebesar $0,000 \leq$ 0,05 sehingga kesimpulan yang didapat adalah variabel bebas yang terdiri dari rasio hutang, ukuran perusahaan, EPS, DPR, DY dan jumlah uang beredar secara bersama-sama berpengaruh terhadap harga saham pada perusahaan sektor pertambangan.

Berdasarkan pada tabel 2, diketahui bahwa: Variabel rasio hutang diketahui koefisien $\beta-0,43$ bernilai negatif menunjukkan bahwa terdapat hubungan yang terbalik atau tidak searah antara variabel rasio hutang terhadap harga saham dan nilai signifikannya yaitu $0,018<0,05$ atau $\mathrm{t}$ hitung $(2,481)>\mathrm{t}$ tabel $(2,035)$ sehingga $\mathrm{H}_{0} 1$ ditolak dan $\mathrm{H}_{\mathrm{a}} 1$ diterima dan dapat disimpulkan bahwa adanya pengaruh antara variabel rasio hutang (debt ratio) dengan harga saham perusahaan dan terdapat hubungan yang terbalik atau tidak searah terhadap harga saham yang berarti jika rasio hutang mengalami peningkatan maka harga saham akan mengalami penurunan dan juga sebaliknya.

Variabel ukuran perusahaan diketahui koefisien $\beta 2,844$ bernilai positif menunjukkan bahwa terdapat hubungan yang searah antara variabel ukuran perusahaan terhadap harga saham dan nilai signifikannya yaitu 0,027 kurang dari 0,05 atau $t$ hitung $(2,319)>\mathrm{t}$ tabel $(2,035)$ sehingga $\mathrm{H}_{0} 2$ ditolak dan $\mathrm{H}_{\mathrm{a}} 2$ diterima, maka dapat disimpulkan bahwa adanya pengaruh antara variabel ukuran perusahaan (Size) terhadap harga saham perusahaan dan terdapat hubungan yang searah (positif) terhadap harga saham, artinya jika ukuran perusahaan mengalami peningkatan maka harga saham juga akan mengalami peningkatan dan juga sebaliknya.

Variabel earning per share diketahui koefisien $\beta \quad 0,756$ bernilai positif menunjukkan bahwa terdapat hubungan yang searah antara variabel EPS terhadap harga saham dan nilai signifikannya yaitu 0,000 lebih kecil dari 0,05 atau t hitung $(15,87)>\mathrm{t}$ tabel $(2,035)$ sehingga $\mathrm{H}_{0} 3$ ditolak dan $\mathrm{H}_{\mathrm{a}} 3$ diterima, maka dapat disimpulkan bahwa adanya pengaruh antara earning per share (EPS) terhadap harga saham perusahaan dan terdapat hubungan yang searah (positif) terhadap harga saham, artinya jika EPS mengalami peningkatan maka harga saham juga akan mengalami peningkatan dan juga sebaliknya.

Variabel dividend payout ratio diketahui koefisien $\beta \quad 0,713$ bernilai positif menunjukkan bahwa terdapat hubungan yang searah antara variabel DPR terhadap harga saham dan nilai signifikannya yaitu 0,000 lebih kecil dari 0,05 atau t hitung $(6,209)>\mathrm{t}$ tabel $(2,035)$ sehingga $\mathrm{H}_{0} 4$ ditolak dan $\mathrm{H}_{\mathrm{a}} 4$ diterima, maka dapat disimpulkan bahwa adanya pengaruh antara dividend payout ratio (DPR) terhadap harga saham perusahaan dan terdapat hubungan yang searah (positif) terhadap harga saham, artinya jika DPR mengalami peningkatan maka harga saham juga akan mengalami peningkatan dan juga sebaliknya.

Variabel dividend yield diketahui koefisien $\beta$ sebesar $-0,423$, bernilai negatif menunjukkan bahwa terdapat hubungan yang terbalik atau tidak searah antara variabel DY terhadap harga saham dan nilai signifikannya yaitu 0,000 lebih kecil 
dari 0,05 atau $\mathrm{t}$ hitung $(5,842)>\mathrm{t}$ tabel $(2,035)$ sehingga $\mathrm{H}_{0} 5$ ditolak dan $\mathrm{H}_{\mathrm{a}} 5$ diterima, maka dapat disimpulkan bahwa adanya pengaruh antara dividend yield (DY) terhadap harga saham perusahaan dan terdapat hubungan yang terbalik atau tidak searah terhadap harga saham yang berarti jika dividend yield (DY) mengalami penurunan maka harga saham akan mengalami kenaikkan dan juga sebaliknya.

Variabel jumlah uang beredar diketahui nilai signifikannya yaitu 0,366 lebih besar dari 0,05 atau $t$ hitung $(0,916)<\mathrm{t}$ tabel $(2,035)$ sehingga $\mathrm{H}_{0} 6$ diterima dan $\mathrm{H}_{\mathrm{a}} 6$ ditolak, maka dapat disimpulkan tidak adanya pengaruh antara variabel jumlah uang beredar (money supply-MS) terhadap harga saham perusahaan. Berdasarkan hasil uji statistik, dapat dirumuskan model regresi sebagai berikut.

$$
\mathrm{SP}=-0,43 \mathrm{DR}+2,844 \text { Size + 0,756 EPS + 0,713 DPR - 0,423 DY + e }
$$

Nilai koefisien determinasi (Adjusted $R^{2}$ ) adalah sebesar 0,951. Artinya besarnya variabel bebas (independen) yaitu rasio hutang, ukuran perusahaan, earning per share, dividend payout ratio, dividend yield dan jumlah uang beredar dapat menjelaskan $95,1 \%$ variasi harga saham. Sedangkan sisanya (100\% - 95,1\% $=4,9 \%$ ) dijelaskan oleh variabel yang lain di luar pada variabel penelitian.

\section{Pengaruh Rasio Hutang terhadap Harga Saham}

Berdasarkan pada hasil pengujian diketahui bahwa rasio hutang (Debt Ratio) berpengaruh terhadap harga saham dan terdapat hubungan yang tidak searah (negatif) dengan harga saham perusahaan. Hal tersebut sesuai dengan hipotesis yang dianjurkan dimana rasio hutang (Debt Ratio) berpengaruh terhadap harga saham. Dengan adanya pengaruh yang negatif tersebut menunjukkan bahwa dengan meningkatnya hutang suatu perusahaan, maka akan dapat mempengaruhi pada penurunan harga saham perusahaan

Hasil penelitian ini mendukung hasil penelitian terdahulu yang dilakukan oleh Viandita dkk. (2013) yang menunjukkan bahwa semakin besar rasio hutang (debt ratio) maka perusahaan tersebut memiliki risiko yang besar pula karena semakin besar beban aset yang akan digunakan oleh perusahaan untuk menjamin hutang maka akan semakin beresiko perusahaan tersebut sehingga hal tersebut direspon negatif oleh investor. hal tersebut juga serupa pada penelitian Hussainey dkk. (2011) dengan hasil penelitian bahwa terdapat pengaruh negatif terhadap harga saham.

\section{Pengaruh Ukuran Perusahaan terhadap Harga Saham}

Berdasarkan pada hasil pengujian diketahui bahwa ukuran perusahaan (Size) berpengaruh terhadap harga saham. Hal tersebut sesuai dengan teori signalling yang dianjurkan dimana ukuran perusahaan (Size) berpengaruh terhadap harga saham. Dengan adanya pengaruh dan arah koefisiennya yang positif terebut ini 
menunjukkan bahwa besar atau kecilnya suatu perusahaan mempengaruhi naiknya harga saham perusahaan.

Hasil penelitian sejalan dengan penelitian Gunarso (2014) juga menunjukkan hasil ukuran perusahaan berpengaruh positif terhadap harga saham karena Ukuran perusahaan yang besar menunjukkan perusahaan mengalami perkembangan sehingga investor merespon positif dan nilai perusahaan akan meningkat diikuti juga pada meningkatnya harga saham perusahaannya.

Hal tersebut juga serupa dengan penelitian Khan (2014) yaitu bahwa ukuran perusahaan berpengaruh positif terhadap harga saham. Ukuran perusahaan yang diukur dengan kapitalisasi pasar menjelaskan size yang kecil akan berisiko tinggi dan tinggi pula harapan pada imbal hasilnya namun minat jumlah investornya lebih sedikit. sedangkan ukuran perusahaan yang besar lebih banyak kekuatan diversifikasi sehingga menurunkan risikonya dan menarik lebih banyak investor.

\section{Pengaruh Earning Per Share terhadap Harga Saham}

Berdasarkan pada hasil pengujian hipotesis penelitian ini menemukan bahwa EPS berpengaruh terhadap harga saham Hal tersebut sesuai dengan hipotesis yang dianjurkan dimana EPS berpengaruh terhadap harga saham perusahaan. Adanya pengaruh ini berarti EPS menjadi ukuran keberhasilan dalam mencapai keuntungan bagi pemilik saham dalam suatu perusahaan sehingga dapat meningkatkan kepercayaan bagi investor. Jadi semakin tinggi nilai EPS, maka dapat meningkatkan juga pada harga saham perusahaan.

Penelitian ini sejalan dengan Viandita dkk. (2013) bahwa pada variabel EPS terdapat pengaruh dan hubungan yang searah (positif) terhadap harga saham. Alasan yaitu Pada dasarnya seorang investor melakukan investasi dengan harapan akan memperoleh keuntungan atas modal yang telah diinvestasikannya. Mereka beranggapan bahwa besarnya nilai laba per lembar saham yang dibagikan oleh sebuah perusahaan merupakan suatu indikator keberhasilan dalam menghasilkan keuntungan bagi pemegang saham. Pola pemikiran tersebut akan mendorong seorang investor untuk melakukan pembelian saham pada perusahaan yang memiliki nilai earning per share yang tinggi. Pada kondisi yang seperti itulah harga saham di pasar modal akan bergerak naik karena meningkatnya jumlah permintaan saham. Selain itu hasil penelitian ini juga mendukung penelitian yang dilakukan oleh Sukhija (2014), Masum (2014), Sharif dkk. (2015), Aveh dan Vitor (2017), Al-Tamimi dkk. (2011) dan Hunjra dkk. (2014) yang menyatakan bahwa EPS berpengaruh secara positif terhadap harga saham.

\section{Pengaruh Dividend Payout Ratio terhadap Harga Saham}

Berdasarkan pada hasil pengujian hipotesis penelitian ini diketahui bahwa DPR berpengaruh terhadap harga saham. Hal tersebut sesuai dengan hipotesis yang dianjurkan di mana DPR berpengaruh terhadap harga saham perusahaan. Adanya pengaruh dan nilai koefisien positif tersebut berarti semakin tinggi nilai 
DPR, maka dapat meningkatkan kepercayaan investor sehingga dapat menaikkan harga saham perusahaan.

Hasil penelitian tersebut sejalan dengan Hunjra dkk. (2014) yang menggunakan dua indikator kebijakan dividen dan pada variabel DPR menunjukkan bahwa hubungan positif berpengaruh terhadap harga saham, karena Hubungan positif antara harga saham dan DPR ini menunjukkan bahwa pemegang saham memilih perusahaan yang memiliki rasio pembayaran dividen tinggi sebab ketika perusahaan membayar dividen, mereka akan mempertahankannya sedikit hal tersebut sehingga akan berdampak positif terhadap harga saham.

\section{Pengaruh Dividend Yield terhadap Harga Saham}

Berdasarkan pada hasil pengujian diketahui bahwa dividend yield berpengaruh terhadap harga saham. Hal tersebut sesuai dengan hipotesis yang dianjurkan dimana dividend yield berpengaruh terhadap harga saham perusahaan. Adanya pengaruh dan nilai koefisien yang negatif ini berarti arah hubungannya terbalik terhadap harga saham. Jadi, semakin tinggi nilai dividend yield, maka dapat menurunkan harga saham perusahaan dan juga sebaliknya jika nilai dividend yield rendah maka dapat meningkatkan harga saham perusahaan.

Hal tersebut tersebut sejalan dengan penelitian Hunjra dkk. (2014) yang menggunakan dua indikator kebijakan dividen dan pada variabel dividend yield menunjukkan bahwa hubungan negatif berpengaruh terhadap harga saham, karena Hubungan negatif antara harga saham menunjukkan bahwa dividend yield semakin rendah, maka dapat meningkatkan harga saham perusahaan.

\section{Pengaruh Jumlah Uang Beredar terhadap Harga Saham}

Berdasarkan pada hasil pengujian diketahui bahwa jumlah uang beredar tidak berpengaruh terhadap harga saham. Hal tersebut tidak sesuai dengan hipotesis dan teori signalling yang dianjurkan dimana jumlah uang beredar berpengaruh terhadap harga saham. Dengan tidak adanya pengaruh ini menunjukkan bahwa dengan meningkatnya jumlah uang beredar tidak mempengaruhi naik turunya harga saham suatu perusahaan.

Hasil penelitian ini konsisten dengan penelitian Kusuma dan Badjra (2016) yang menunjukkan hasil bahwa jumlah uang beredar tidak berpengaruh terhadap harga saham. Tidak berpengaruhnya jumlah uang beredar ini lebih banyak didominasi oleh tingginya beban biaya bunga simpanan yang dikapitalisasi dan ekspansi pada beberapa komponen tagihan bersih kepada pemerintah terutama pembayaran dalam rangka program penjaminan terhadap kewajiban perbankan dan pembayaran kupon obligasi rekapitalisasi bank. Sehingga peningkatan jumlah uang beredar yang benar-benar dipegang oleh masyarakat sangat kecil dan tidak berpengaruh sama sekali terhadap peningkatan harga saham karena tidak ada tambahan dana yang ada di masyarakat yang dapat digunakan untuk investasi di pasar modal. 


\section{KESIMPULAN}

Berdasarkan hasil penelitian, dapat disimpulkan bahwa pada variabel rasio hutang, ukuran perusahaan, earning per share, dividend payout ratio, dividend yield berpengaruh terhadap harga saham perusahaan, sedangkan variabel jumlah uang beredar tidak berpengaruh terhadap harga saham. Sehingga determinant yang mempengaruhi harga saham hanya dari internal perusahaan.

Keterbatasan penelitian ini yaitu hanya mengunakan perusahaan sektor pertambangan dan data harga saham menggunakan closing price tahunan, oleh karena itu rekomendasi bagi peneliti selanjutnya, agar mendapat hasil secara umum dan luas objek penelitian tidak terbatas hanya pada perusahaan pertambangan, tetapi bisa juga seluruh perusahaan yang terdaftar di BEI. Selain itu juga bisa memperbanyak populasi penelitian dan menggunakan nilai rata-rata mingguan atau bulanan pada proxy harga saham sehingga dapat mencerminkan keadaan harga saham yang mengalami fluktuasi pada tahun tertentu.

\section{REFERENSI}

Al-Tamimi, H. A. H., Alwan, A. A. and Rahman, A. A. A. (2011). Factors Affecting Stock Prices in the UAE Financial Markets. Journal of Transnational Management. Vol. 16(1) : 3-19

Akbar, M., Ali, S. and Khan, M. F. (2012). The relationship of stock prices and macroeconomic variables revisited: Evidence from Karachi stock exchange Journal of Business Management. Vol. 6(4) 1315-1322

Anastassia dan Firnanti, F.(2014). Faktor-Faktor Yang Mempengaruhi Vol.atilitas Harga Saham Pada Perusahaan Publik NonKeuangan. Jurnal Bisnis dan Akuntansi. Vol. 16(2) : 95-102

Aveh, F. K. and Vitor, A. D. (2017). Firm-specific determinants of stock prices in an emerging capital market: Evidence from Ghana Stock Exchange. Journal Economics and Finance. Vol. 5(1): 1-11

Azizah, S. (2016). Pengaruh faktor internal dan eksternal perusahaan terhadap nilai perusahaan pada perusahaan manufaktur. Jurnal Ilmu dan Riset Akuntansi. Vol. 5(10) : 120

Barakat, A. (2014). The Impact of Financial Structure, Financial Leverage and Profitability on Industrial Companies Shares Value: Applied Study on a Sample of Saudi Industrial Companies. Journal of Finance and Accounting. Vol. 5(1) : 55-66

Bosupeng, M. (2014). Sensitivity Of Stock Prices To Money Supply Dynamics. International Journal of Novel Research in Marketing Management and Economics. Vol. 1, Iss 1, : 58-65 
Brigham, E. F. dan Houston, J. F.(2011). Dasar-dasar Manajemen Keuangan. Jakarta: Salemba Empat.

Buigut, K., Soi, N., Koskei, I. and Kibet, J. (2013). The Effect of Capital Structure on Share Price On Listed Firms In Kenya: A Case of Energy Listed Firms. European Journal of Business and Management. Vol. 5(9) : 29-34

Fahmi, Irham. (2015). Manajemen investasi: Teori dan Soal Jawab. Edisi kedua. Jakarta: Salemba Empat

Ghauri, S. M. K. (2014). Determinants of changes in share prices in banking sector of Pakistan. Journal of Economic and Administrative Sciences. Vol. $30(2): 121-130$

Gunarso, P. (2014). Laba Akuntansi, Leverage dan Ukuran Perusahaan Terhadap Harga Saham Di Bursa Efek Indonesia. Jurnal Keuangan dan Perbankan. Vol. 18(1) : 63-71

Hadi, N. 2013 Pasar Modal: Acuan Teoritis dan Praktis Investasi di Instrumen Keuangan Pasar Modal. Edisi Pertama. Graha Ilmu: Yogyakarta

Herlambang, Sugiarto dan Baskara Said Kalana. 2001. Ekonomi Makro: Teori Analisis dan Kebijakan. Jakarta: Gramedia Pustaka Utama.

Hunjra, A. I., Ijaz, M. S., Chani, M. I., Hassan, S. U. and Mustafa, U. (2014). Impact of Dividend Policy, Earning per Share, Return on Equity, Profit after Tax on Stock Prices. International Journal of Economics and Empirical Research. Vol. 2(3): 109-115.

Hussainey, K., Mgbame, C. O. and Chijoke-Mgbame, A. M. (2011). Dividend policy and share price Vol.atility: UK evidence. The Journal of Risk Finance. Vol. 12(1) : 57-68

Khan, A. (2014). How Does Stock Prices Respond to Various Macroeconomic Factors?: A Case Study of Pakistan. Journal of Management. Vol. 4(1) : $75-95$

Khan, K. I. (2012). Effect of Dividends on Stock Prices: A Case of Chemical and Pharmaceutical Industry of Pakistan. Journal on Business Management. Vol 2(5) : 141-148

Kodrat, D. S. dan Indonanjaya, K. (2010). Manajemen Investasi: Pendekatan teknikal dan fundamental untuk analisis saham. Yogyakarta: Graha Ilmu

Kusuma, I Putu M. E. dan Badjra, I. B. (2016). Pengaruh Inflasi, JUB, Nilai Kurs Dollar Dan Pertumbuhan GDP Terhadap IHSG Di Bursa Efek Indonesia. E Jurnal Manajemen Unud. Vol. 5(3) : 1829-1858 
Masum, Al Abdullan. (2014). Dividend Policy at Its Impact on Stock Price - A study on Commercial Bank Listed in Dhaka Stock Exchange. Journal of Global Disclosure of Economics and Business. Vol. 3 ( 1) : 9-17

Murhadi, W. R. (2015). Analisis Laporan Keuangan Proyeksi dan Valuasi Saham. Jakarta: Salemba Empat.

Naresh, K Malhotra. 2010. Marketing Research : An Applied Orientation Edisi 6. USA: Pearson Education.

Nuel, Y. (2015). Pengaruh Rasio Likuiditas, Solvabilitas dan Profitabilitas terhadap Harga Saham Perusahaan Sub Sektor Perkebunan Kelapa Sawit di Bursa Efek Indonesia. E-Journal Administrasi Bisnis. Vol. 3(4) : 806820

Riyanto, B. (2008). Dasar-dasar Pembelanjaan Perusahaan. Yogyakarta: Penerbit GPFE

Sartono, R. A. (2010). Manajemen keuangan: Teori dan Aplikasi. Edisi keempat. Yogyakarta: BPFE

Samsul, M. (2006). Pasar Modal dan Manajemen portofolio. Jakarta: Erlangga

Sharif, I., Ali, A. and Jan, F. A. (2015). Effect of Dividend Policy on Stock Prices. Journal of Management. Vol. 6(1) : 55-85

Sukhija, S. (2014). A Study regarding Analyzing Recessionary Impact on Fundamental Determinants of Stock Prices in India share market. European Journal of Business and Management. Vol..6 (4) : 161-168

Soda, E. (2016). PwC : Tahun 2015 Sebagai Tahun Terburuk Bagi Sektor Pertambangan, (Online), (www.tambang.co.id/pwc tahun-2015-sebagai tahun terburuk-bagi-sektor-pertambangan-12692, (diakses pada tanggal 30 Maret 2017).

Viandita, T. O., Suhadak. Dan Husaini, A. (2013). Pengaruh Debt Ratio, Price to Earning Ratio, Earning Per Share dan Size Terhadap Harga Saham:Studi pada Perusahaan Industri Yang Terdaftar Di Bursa Efek Indonesia. Jurnal Administrasi Bisnis. Vol. 1(2) : 113 -121

Warrad, L. (2016). The Analysis of Capital Structure and Performance on the Jordanian Banks Share Price European Journal of Business and Management. Vol. 8 (20): 113-118 